\title{
How do tree- and stand-level factors influence belowground biomass and carbon storage in tanoak (Notholithocarpus densiflorus)?
}

\author{
by Brandon H. Namm" and John-Pascal Berrill ${ }^{1,2}$
}

\begin{abstract}
Tanoak (Notholithocarpus densiflorus) is the most common hardwood in northern California forests, yet its capacity for belowground carbon storage is unknown. To study relationships between coarse roots and tree and stand variables, we destructively sampled twelve tanoak root systems in Humboldt County, California. To estimate belowground biomass, we summed measured biomass of the root ball and a subsample of lateral roots along with predicted biomass of unmeasured coarse roots. Tree size was the best linear predictor of belowground biomass and carbon, indicating that a $25-\mathrm{cm}$ diameter tanoak, for example, stored $70 \mathrm{~kg}$ of biomass and $34 \mathrm{~kg}$ of carbon in its root system. Stand density was also influential: a doubling of stand density index reduced belowground carbon by $22 \%$ for the average tanoak. The mean root-toshoot ratio of 0.35 varied between 0.11 and 0.65 , with larger tanoak at high stand densities allocating proportionally less biomass belowground than small open-grown tanoak. The findings highlight the importance of accounting for stand density effects, otherwise belowground carbon will be under predicted in low-density stands managed for tree health, vigor, and resistance to drought and wildfire, or overestimated in forests managed at high densities for high carbon sequestration.
\end{abstract}

Key words: biomass allocation, coarse root biomass, forest carbon sequestration, root-to-shoot ratio, tree root systems.

\section{RÉSUMÉ}

Le chêne à $\tan$ (Notholithocarpus densiflorus) représente le feuillu le plus commun dans les forêts du nord de la Californie, mais sa capacité de stockage de carbone souterrain est inconnue. Afin d'étudier les relations entre les variables des racines principales, de l'arbre et du peuplement, nous avons procédé à un échantillonnage destructif du système racinaire de douze chênes à tan du comté de Humboldt en Californie. Pour estimer la biomasse souterraine, nous avons additionné la biomasse mesurée de la motte avec un sous-échantillon des racines latérales accompagnée la biomasse estimée des grosses racines non mesurées. La taille de l'arbre s'est avérée être le meilleur prédicteur linéaire de la biomasse souterraine, indiquant que par exemple pour un chêne ayant un diamètre de $25 \mathrm{~cm}$, la biomasse racinaire était de $70 \mathrm{~kg}$ et de $34 \mathrm{~kg}$ de carbone stocké. La densité du peuplement exerçait également une influence : une valeur double de l'indice de densité du peuplement a entraîné une réduction de $22 \%$ du carbone souterrain pour un chêne de taille moyenne. Le ratio moyen entre le système racinaire et le système foliacé de 0,35 a fluctué entre 0,11 et 0,65 , alors que les plus gros chênes dans les peuplements de forte densité affichaient proportionnellement moins de biomasse souterraine que les petits chênes des peuplements de faible densité. Ces résultats soulignent l'importance des effets de la densité du peuplement, ce qui autrement indiquerait que le carbone souterrain serait sous-estimé dans les peuplements aménagés pour favoriser la santé des arbres, leur vigueur et leur résistance à la sécheresse et au feu, ou serait surestimé dans les peuplements aménagés à forte densité pour stocker du carbone en grande quantité.

Mots clés : allocation de la biomasse, biomasse des racines principales, séquestration du carbone forestier, ratio systèmes racinaire/foliaire, systèmes racinaires des arbres

\footnotetext{
${ }^{1}$ Department of Forestry and Wildlife Resources, Humboldt State University, Arcata, CA 95521, USA

${ }^{2}$ School of Forest Resources, University of Maine, Orono, ME 04469, USA
} 


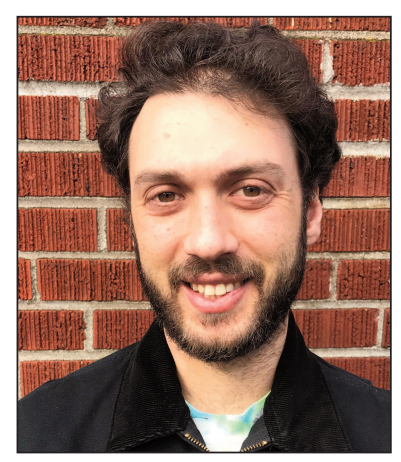

Brandon H. Namm

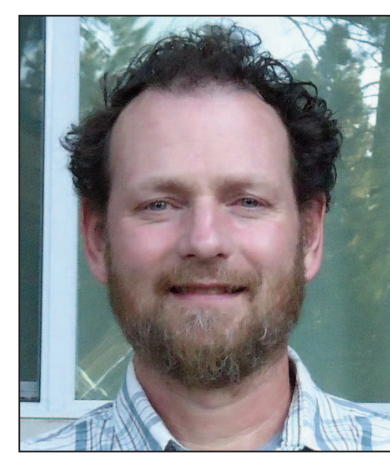

John-Pascal Berrill

\section{Introduction}

Estimates of belowground biomass and carbon (C) stored in tree roots allow us to better understand how disturbances, management, and climate changes affect the global $\mathrm{C}$ cycle. Atmospheric greenhouse gas reduction via sequestering and storing $\mathrm{C}$ belowground is an important ecosystem service that is difficult to quantify reliably. Obtaining information about belowground biomass and $\mathrm{C}$ is challenging due to roots' variable distribution in the soil and underestimation of biomass in non-destructive sampling (Böhm 1979). These challenges have encouraged development of allometric models that relate easily measurable parameters, such as diameter at breast height (dbh) to belowground biomass and C (e.g., Drexhage and Colin 2001).

Ideally, allometric models (Huxley and Teissier 1936) would incorporate additional parameters representing differential allocation of resources above- or belowground depending on physiological and environmental factors (Niklas 2004). The ratio of belowground biomass to aboveground biomass, or the root-to-shoot (R:S) ratio, is known to vary among species and according to tree size and age, climate and site factors, and neighbor competition (Cairns et al. 1997; Waring and Powers 2017). A lower R:S ratio in a dense forest, for example, may indicate that trees allocated more carbohydrates to height growth because light was the resource most limiting growth (Bolte et al. 2004). Incorporating key factors (and their interactions) that affect $C$ storage in tree roots into predictive models would allow us to predict shifts in patterns of C storage. Such shifts could be related to alteration of stand structure from management of forest ecosystems or changes due to forest health problems, natural disturbances, or climate change. A higher priority for belowground data collection and model development could be assigned to ubiquitous species with high capacity to sequester and store atmospheric $\mathrm{C}$ throughout their range and that are also vulnerable to loss.

Tanoak (Notholithocarpus densiflorus (Hook. \& Arn.) Manos, Cannon \& S.H. Oh) is a common hardwood species found along the west coast of the United States from Santa Barbara County, California to the central coast of Oregon. Tanoak produces nuts similar to acorns that are an important source of sustenance for wildlife including birds, mammals, and insects (Tappeiner et al. 1990). Tanoak is threatened by the spread of a non-native disease called sudden oak death (SOD). Sudden oak death is caused by the oomycete Phytopthora ramorum and infects many host species including California bay-laurel (Umbellularia californica (Hook. \& Arn.) Nutt.), coast Douglas-fir (Pseudotsuga menziesii var. menziesii (Mirbel) Franco), coast redwood (Sequoia sempervirens (D. Don Endl.), and several oak species (Quercus spp.) but it inflicts the greatest disease severity and highest fatality on tanoak (Rizzo et al. 2002; McPherson et al. 2010). Ecological implications of SOD are increased fire severity (Kuljian and Varner 2010; Metz et al. 2011) and decreased water quality due to soil erosion (Rizzo et al. 2005). Widespread tanoak mortality would likely create an opportunity for niche occupation by other species (Ramage et al. 2011). Many of these species do not offer this same suite of ecosystem benefits, have lower wood density and hence store less carbon per unit volume than tanoak.

Unknown is how much belowground biomass and C currently stored in tanoak root systems would be lost as tanoak succumbs to SOD. Sudden oak death kills the whole tree including the root system, but other forms of disturbance, such as fire and timber harvest, leave the root system intact. Cut or fire-killed tanoak stems regenerate quickly via basal stump sprouts originating from belowground burls (lignotubers). These sprouts can persist in the understory of forests with dense canopies due to tanoak's shade tolerance and ability to regenerate in shaded conditions (Baker 1949; Hunter 1997). Tanoak sprouts can also grow quickly in high light after major disturbances (Harrington and Tappeiner 1997, 2009; Berrill et al. 2018). It is common for tanoaks to outcompete commercial conifer species regenerating more slowly by seed or planting, especially after stand replacing disturbances (Harrington and Pabst 1994; Harrington and Tappeiner 1991, 1997). We expect the established root system of a re-sprouting tanoak to have a competitive advantage over newly-established seedlings in soil resource acquisition (Brassard et al. 2009). Although tanoak adversely affects the growth of merchantable species such as redwood (Berrill and O'Hara 2014; Berrill and Howe 2019) and Douglas-fir (Harrington and Tappeiner 2009), it is an important resource for wildlife and continues to store $\mathrm{C}$ in a root system that re-sprouts after disturbance. While tanoak above-ground biomass can already be predicted for a large geographical extent (Snell and Little 1983), we found no species-specific models predicting belowground biomass and C. Our objective was to develop allometric belowground biomass and $\mathrm{C}$ models for tanoak across a wide range of tree sizes. We (i) analyzed the effect of tree size, stand density, crown position, and species composition of neighbor trees on R:S biomass ratio in tanoak; and, (ii) developed allometric models that best describe belowground biomass and $\mathrm{C}$ in tanoak using tree- and stand-level variables as predictors

\section{Methods}

Site description

Tanoak root systems were excavated at the 148 ha L.W. Schatz Demonstration Tree Farm (LWSDTF) in Humboldt County, California ( $40^{\circ} 46^{\prime} 49^{\prime \prime} \mathrm{N}, 123^{\circ} 52^{\prime} 21^{\prime \prime} \mathrm{W}$ ). Before harvesting in the 1950s, the site was occupied predominantly by an old-growth Douglas-fir forest with tanoak and California bay associates. Species composition now consists primarily of tanoak intermingled with young, planted and naturally regenerated Douglas-fir, and occasional naturally regenerated grand fir (Abies grandis (Douglas ex D. Don) Lindl.) and western dogwood (Cornus nuttallii (Audubon) Moldenke) (West 2007). Soils consist mainly of Ultisols (Colwell et al. 
1954), which are strongly leached, acidic forest soils with relatively low native fertility. However, due to the favorable climate regimes in which they are typically found, Ultisols often support productive forests (McDaniel 2012). Climate at the LWSDTF is characterized by cool wet winters and warm dry summers. Snow is rare, with most of the annual 30-year average precipitation of $1652 \mathrm{~mm}$ coming as rain between November and April. August is the warmest month with a 30 -year average temperature of $18.3^{\circ} \mathrm{C}$ and January the coolest with a 30 -year average temperature of $7.9^{\circ} \mathrm{C}$ (http://www.prism.oregonstate.edu).

\section{Excavation methods}

Belowground biomass was estimated by destructively sampling twelve tanoak trees that covered a range of tree sizes and crown positions, with consideration of machine access for the excavation. An excavator was used to dig a narrow trench (that formed a square) around each tanoak. The excavation areas encompassing the sample trees and their trenches were 4 $\mathrm{m}^{2}(2 \mathrm{~m} \times 2 \mathrm{~m})$ square areas all oriented in the same direction and proceeded to a depth of $1 \mathrm{~m}$, to where roots were no longer visible. The volume excavated remained consistent regardless of tree size. This method severed roots at the edge of the excavated area. Within the excavated area, we measured the end diameter and path length from the lignotuber for all roots greater than $1 \mathrm{~mm}$ in diameter at the point of severance. Roots outside the excavated area were sub-sampled in eight cardinal directions around the tree. All root wood within the excavated area and all the roots sub-sampled outside the excavated area were dried at $65^{\circ} \mathrm{C}$ and weighed. Drying duration varied by root size, but all samples were dried until a consistent mass was attained. Namm and Berrill (2016) provide additional detail regarding the destructive field sampling procedure and the sample processing protocols.

\section{Field measurements}

To identify aboveground variables affecting belowground biomass and $\mathrm{C}$ allocation in tanoak, we measured the dbh of each excavated tree, diameter at ground level, total height, live crown height, crown radius, and crown position. A diameter tape and laser rangefinder were used to collect the aboveground variables. Because tanoaks often produce several stems from a single root system (Tappeiner et al. 1990), total BA for the excavated trees was obtained by summing the BA of each individual stem. A circular fixed-area 0.02 ha plot was centered on each sample tree and all neighboring trees greater than $5 \mathrm{~cm}$ dbh were measured. Aboveground measurements on each neighbor tree included $\mathrm{dbh}$, total height, live crown height, crown radius, and crown position. Crown volume for all neighbor and excavated trees was modeled as a parabola using crown radius and live crown height. Sampled areas had no visible evidence or record of recent disturbance that might have altered R:S ratio.

\section{Model description for simulated roots}

The subsample of roots extending beyond the excavated area were used to develop models predicting root biomass and $\mathrm{C}$ for the remainder of the root system. Models describing root morphology (Namm and Berrill 2016) were developed and organized together to reconstruct individual root size and length, and predict biomass and $\mathrm{C}$ not sampled during the excavation. For this root reconstruction model, the end diameter of severed roots within the excavated area and their path lengths from the lignotuber were used for initial input. Root sections with two measurable ends were represented as frustums. The frustum's small-end cross-sectional area $\left(\mathrm{CSA}_{\text {small-end }}\right)$ was calculated with the deteriorating compound interest rate equation:

\section{1) $C S A_{\text {small-end }}=\operatorname{MLC}\left[e^{-T R(M L)}\right]$}

Where, MLC was the frustum's large-end cross-sectional area $\left(\mathrm{cm}^{2}\right)$, TR was the taper rate (percent decrease in cross-sectional area $\left.\mathrm{cm}^{-1}\right)$, and $\mathrm{ML}$ was length of the frustum $(\mathrm{cm})$.

A fork was appended to the small-end of any frustum greater than $1 \mathrm{~mm}$ in diameter. Using the statistical package R (R Development Core Team 2017), each root segment (which included the frustum and its subsequent fork) was assigned an identifying number so that root simulation continued along a series of segments until reaching $1 \mathrm{~mm}$ in diameter. The model continually looped back to the previous root segment until all the segments for the reconstructed root had been simulated. A random number within a Poisson distribution defined the number of branches resulting from each root section. The length of the root segment was the parameter used to determine the quantity of branches (Namm and Berrill 2016). Branches were appended to their parent root section, (halfway along parent section length), and were programmed with the same fork and branch protocols as the other root segments.

The constant proportional bark volume and the increase in root wood percent $\mathrm{C}$ with path length from the lignotuber (Namm and Berrill 2012) were accounted for in calculations of simulated root biomass and $\mathrm{C}$ estimates. Carbon content of roots within the excavated area was estimated by applying the average $\mathrm{C}$ content for both the lignotuber and the roots adjacent to the edge of the excavated area to their total dry mass. The excavated biomass, roots sampled beyond the excavated area, and predicted biomass of roots not sampled outside the excavated area were summed to estimate total belowground biomass for the 12 sample trees. We then applied an adjustment for the within-tree gradient in percent $\mathrm{C}$ based on path length distance from the lignotuber $\left(0.005 \% \mathrm{~cm}^{-1}\right.$, Namm and Berrill 2012).

\section{Model evaluation}

Biomass estimates for the simulated roots were bootstrapped by running the model one, 10, 100 and 1000 times on each set of input parameters (root diameter and path length from the lignotuber). Results were compared to determine whether biomass estimates of simulated roots became less variable with greater numbers of model iterations.

To determine whether the combination of morphological models produced accurate estimates of roots lost during excavation, roots were simulated using the same path length from the lignotuber and starting diameter as the actual roots sampled outside the excavated area. The residuals in terms of differences between actual and predicted root biomass were examined. Residual values equally and non-sequentially distributed above and below the zero residual line would indicate 
that error did not systematically occur for roots of a certain size. The biomass of roots sampled outside the excavation area was also regressed against their large-end diameter where they were severed during excavation. This simple allometric diameter-to-mass model was used to predict root mass lost during excavation and total root system biomass, and its predictions were compared against morphological model predictions.

\section{Testing for influence of stand variables}

Linear mixed-effect models were constructed using PROC GLIMMIX in SAS (SAS Institute Inc. 2011) to detect whether aboveground variables measured on the excavated tanoak, the presence of Douglas-fir, or stand density index (SDI) affected the relationship between tanoak tree total BA and belowground biomass or $\mathrm{C}$ content. The summation of individual tree stem SDI values gave SDI for the plot centered on each excavated tanoak. To account for pseudo-replication in SDI calculations caused by overlap of the 0.02 ha fixed-area plots, excavated trees sharing a neighbor were considered part of the same block, with trees nested in blocks. Therefore a random effect was specified as block. Kenward-Roger degrees of freedom adjustment was used to account for the unbalanced experimental design (i.e., different number of excavated trees per block). We used Akaike's Information Criterion for small samples $\left(\mathrm{AIC}_{\mathrm{c}}\right.$ ) to select among plausible models because our sample conformed to the guideline that $\mathrm{n} /$ maximum number of predictors $<40$ (Burnham and Anderson 2008). For each model we also calculated adjusted $\mathrm{R}^{2}$ and the root mean square error (RMSE) to quantify goodness of fit.

\section{Modeling root-to-shoot ratio}

Basal area data for the excavated trees were applied to existing allometric models of aboveground biomass in tanoak. These allometric models were developed to estimate aboveground biomass from dbh for tanoak $2.0 \mathrm{~cm}$ to $66.0 \mathrm{~cm}$ dbh at various sites in Washington and northern California (Snell and Little 1983). To estimate the total aboveground biomass for root systems with multiple stems, we applied Snell and Little's (1983) aboveground biomass model individually to each tanoak stem and summed the biomass for all the stems originating from the same excavated root system. The ratio of these estimates of aboveground biomass and our predictions of belowground biomass gave R:S biomass ratios. The R:S ratio was regressed against the following explanatory variables: plot BA or SDI, tanoak tree BA or circumference, crown position (binary: dominant or suppressed), and a dummy variable for the presence of Douglas-fir trees within the fixed area plot around each excavated tanoak. These variables each represented a factor hypothesized to affect R:S ratio: tree size, stand density, crown position, and species composition. Tree BA was transformed to reduce skewness. Due to the small sample size, $\mathrm{AIC}_{\mathrm{c}}$ was the criterion for model selection (Burnham and Anderson 2008).

\section{Results}

Among the 12 excavated tanoak trees, 59\% had one stem, $33 \%$ had two stems, and $8 \%$ had three stems supported by individual root systems. The excavated trees had a combined stem BA between $0.006 \mathrm{~m}^{2}$ and $0.22 \mathrm{~m}^{2}$, and the dbh of individual stems were between $1.9 \mathrm{~cm}$ and $52.4 \mathrm{~cm}$ (Table 1).
Tree heights ranged from $2.7 \mathrm{~m}$ to $21.1 \mathrm{~m}$, and crown volumes ranged from 3.3 to $44.9 \mathrm{~m}^{3}$. Tree species within the fixed area plots consisted of Douglas-fir, tanoak, and one western dogwood. Douglas-fir was the dominant species, comprising $53 \%$ of the total BA within the 0.02 ha fixed-area plots, while tanoak comprised $45 \%$ and dogwood made up two percent. Five different blocks were identified, and the greatest neighbor overlap occurred in one block containing six excavated tanoak.

The correlation between measured biomass of roots sampled beyond the excavated area and the predicted biomass obtained by regressing the cross-sectional area and biomass of roots sampled beyond the excavated area $\left(R^{2}=0.78\right)$ was much weaker than when using the morphological models to predict the biomass of roots measured beyond the excavated area $\left(R_{\text {adj }}^{2}=0.99,1000\right.$ iterations per root). The regression between roots measured outside the excavated area and roots simulated using morphological models had a slope of 1.02, where a slope of 1 reflects perfect average prediction accuracy (Fig. 1). This high level of accuracy for estimates of biomass in the simulated roots was attained after increasing the number of model iterations to 1000 . In terms of prediction precision, $95 \%$ of the estimated root biomass data were within + $31 \%$ of the measured root biomass after 1000 model iterations. On average, simulated roots accounted for $7.8 \%$ of the total belowground biomass, ranging from $2.3 \%$ to $14.1 \%$.

\section{Root-to-shoot ratio models}

The mean R:S biomass ratio for the 12 excavated tanoaks was 0.35 , ranging between 0.11 and 0.65 . Root-to-shoot ratio decreased with tree size in terms of stem BA (summed for multiple-stem tanoak). The relationship between tree BA and tanoak R:S ratio $\left(\mathrm{R}^{2}\right.$ adj $\left.=0.79, \mathrm{RMSE}=0.091\right)$ was best described by the model with lowest AICc:

2) $\operatorname{Sin}^{-1}\left(R S^{0.5}\right)=0.2713-0.1052(\ln B A)$

Where $\sin ^{-1}\left(R S^{0.5}\right)$ was the arcsine square root transformed $\mathrm{R}: S$ ratio of total biomass $(\mathrm{kg})$ belowground (excluding stump) and predicted aboveground biomass including stump, stem, branches, bark, and foliage from Snell and Little (1983).

The dummy variable for presence of Douglas-fir neighbors was not significant $(p=0.53)$, indicating that there was no evidence that R:S ratio in tanoak was differentially affected by Douglas-fir neighbors relative to hardwood neighbors in our small sample $(n=12)$. Estimates of the R:S ratio were improved by including predictor variables for plot SDI, the interaction between tanoak tree BA and plot SDI, and a dummy variable for crown position, indicating that suppressed trees had lower R:S ratios $\left(\mathrm{R}^{2}\right.$ adj. $=0.92$, RMSE $=$ 0.062 ). However, parameter estimates for all variables except tree BA had large standard errors and p-values $\alpha 0.05$, so we rejected this over-parameterized model. The model that accounted for the most variation in the tanoak R:S ratio included tree $\mathrm{BA}$ and the interaction between $\mathrm{BA}$ and SDI $\left(\mathrm{R}^{2}{ }_{\text {adj. }}=0.92, \mathrm{RMSE}=0.057\right.$, Fig. 2$)$, such that:

$$
\text { 3) } \begin{aligned}
\operatorname{Sin}^{-1}\left(R S^{0.5}\right)= & 0.2642-0.1435(\ln B A) \\
& +0.000054(\ln B A * S D I)
\end{aligned}
$$


Table 1. Aboveground variables measured and estimated biomass and carbon for excavated tanoak trees with single or multiple stems

\begin{tabular}{|c|c|c|c|c|c|c|c|c|}
\hline Tree & Stem & $\begin{array}{l}\mathrm{dbh} \\
(\mathrm{cm})\end{array}$ & $\begin{array}{c}\text { Diameter at } \\
\text { base }(\mathrm{cm})\end{array}$ & $\begin{array}{l}\text { Height } \\
\text { (m) }\end{array}$ & $\begin{array}{l}\text { Live crown base } \\
\text { height }(\mathbf{m})\end{array}$ & $\begin{array}{l}\text { Belowground } \\
\text { biomass (kg) }\end{array}$ & $\begin{array}{l}\text { Belowground } \\
\text { carbon (kg) }\end{array}$ & Crown position \\
\hline 1 & 1 & 15.9 & 17.2 & 14.1 & 5.3 & 22.2 & 10.9 & suppressed \\
\hline 2 & 1 & 33.5 & 39.6 & 21.1 & 4.0 & 147.3 & 72.0 & dominant \\
\hline 3 & 1 & 47.0 & 54.5 & 16.7 & 10.3 & 133.5 & 65.3 & dominant \\
\hline 4 & 1 & 34.8 & 42.1 & 18.3 & 13.3 & 107.8 & 52.8 & dominant \\
\hline 5 & 1 & 52.4 & 60.1 & 20.7 & 8.5 & 343.8 & 168.2 & dominant \\
\hline 6 & 1 & 42.9 & 51.5 & 19.7 & 8.1 & 190.7 & 93.4 & dominant \\
\hline 7 & 1 & 11.1 & 17.4 & 11.6 & 7.7 & 23.6 & 11.4 & suppressed \\
\hline \multirow[t]{2}{*}{8} & 1 & 8.2 & 13.0 & 5.2 & 1.7 & 14.0 & 6.8 & suppressed \\
\hline & 2 & 2.5 & 5.5 & 3.1 & 1.5 & - & - & suppressed \\
\hline \multirow[t]{3}{*}{9} & 1 & 3.1 & 5.5 & 3.4 & 1.6 & 6.2 & 3.0 & suppressed \\
\hline & 2 & 3.6 & 6.1 & 3.7 & 1.4 & - & - & suppressed \\
\hline & 3 & 1.9 & 3.8 & 2.7 & 1.1 & - & - & suppressed \\
\hline \multirow[t]{2}{*}{10} & 1 & 6.5 & $67.3^{\star}$ & 20.7 & 14.8 & 203.3 & 99.5 & dominant \\
\hline & 2 & 40.6 & $67.3^{*}$ & 20.7 & 13.0 & - & - & dominant \\
\hline \multirow[t]{2}{*}{11} & 1 & 30.7 & 35.3 & 19.7 & 10.5 & 260.0 & 127.2 & dominant \\
\hline & 2 & 36.3 & 43.4 & 20.3 & 9.9 & - & - & dominant \\
\hline \multirow[t]{5}{*}{12} & 1 & 8.5 & 10.5 & 4.6 & 1.4 & 9.8 & 4.8 & suppressed \\
\hline & 2 & 5.8 & 8.9 & 7.2 & 1.5 & - & - & suppressed \\
\hline & Min. & 1.9 & 3.8 & 2.7 & 3.3 & 6.2 & 3.0 & - \\
\hline & Max. & 52.4 & 67.3 & 21.1 & 14.8 & 343.8 & 168.2 & - \\
\hline & Mean & 23.6 & 31.3 & 13.0 & 6.4 & 121.8 & 59.6 & - \\
\hline
\end{tabular}

* Double-stemmed tanoak with separate stems at dbh but sharing a single stem at ground level.

The positive interaction coefficient for tree BA and plot SDI and the negative coefficient for tree BA indicated that R:S ratio estimates were greater among smaller tanoak (less BA), and tanoak in areas of lower SDI (Fig. 2). This model was more informative than the simpler R:S ratio-tree BA model, and the coefficients were significant in terms of p-values (p 0.01), however the model was only the second best in terms of AICc.

Allometric models of belowground biomass and $\mathrm{C}$

Simpler models had better (lower) $\mathrm{AIC}_{\mathrm{c}}$ scores than more complex models predicting belowground biomass and $\mathrm{C}$. Models without the dummy variable for multiple-stemmed tanoak had lower $\mathrm{AIC}_{\mathrm{c}}$ scores, indicating that a difference in belowground biomass between single- and multiple-stemmed tanoak (with equivalent BA) was not detected. Modeling tanoak belowground biomass using the predictors BA, crown position, and SDI explained the most variation in the data (Table 2). However, there was uncertainty around model coefficients for SDI $(\mathrm{p}=0.12)$ and crown position $(\mathrm{p}=0.14)$. Using this model, a suppressed tanoak with the average BA of $0.076 \mathrm{~m}^{2}$, or singlestemmed dbh of $31.1 \mathrm{~cm}$, located in a stand with the maximum SDI of 1118 was estimated to hold $43 \mathrm{~kg}$ of biomass belowground. Alternatively, an open-grown (i.e., minimum SDI of 75) dominant tanoak with the same BA was expected to store 165 $\mathrm{kg}$ of biomass belowground.

The best model in terms of $\mathrm{AIC}_{\mathrm{c}}$ included only $\mathrm{BA}$ as a predictor (Table 2). Belowground biomass and tree BA expressed a positive linear relationship when both axes were projected onto a logarithmic scale (Fig. 3). Using this model, a tanoak with the average tree BA of $0.076 \mathrm{~m}^{2}$ was expected to store 98 $\mathrm{kg}$ of biomass belowground. A model containing plot SDI and 

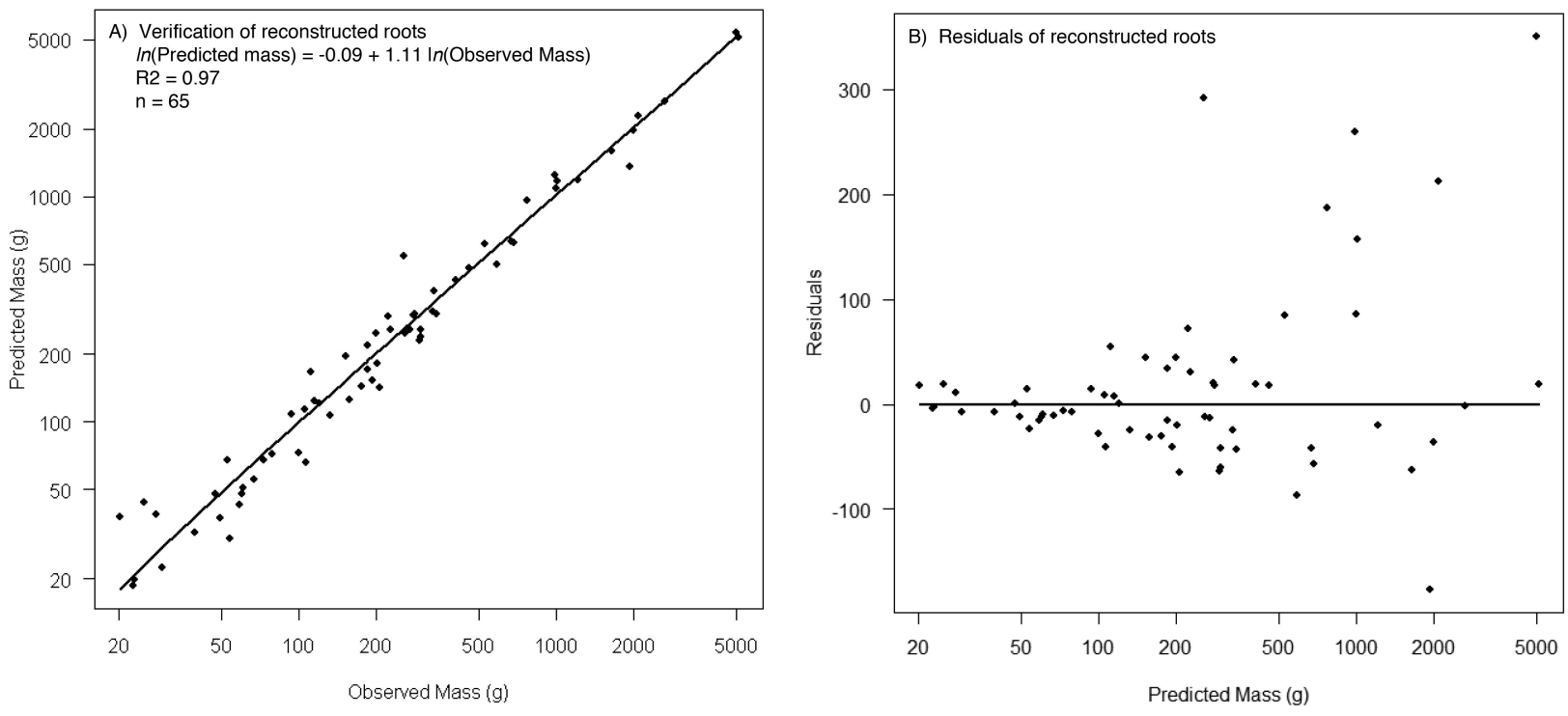

Fig. 1 Comparing lateral root data and predictions from root morphology models of Namm and Berrill (2016). a) Observed mass of roots measured outside the excavated area against the mass of modeled roots provided the same parameters of path length from the lignotuber and starting diameter. b) Residual values for predicted root mass; where residual = predicted - actual

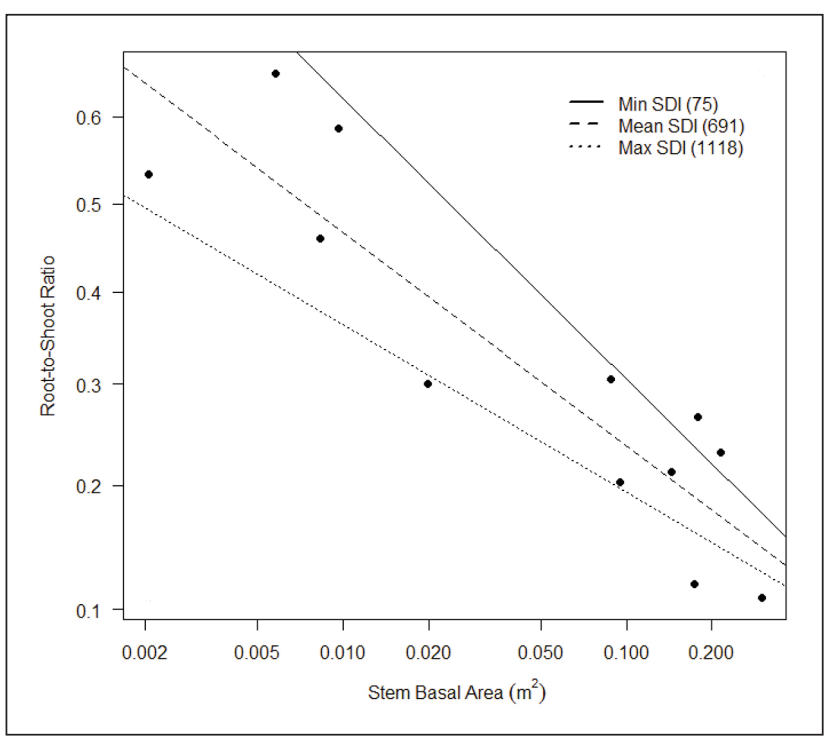

Fig. 2 Tanoak root-to-shoot biomass ratio as a function of stem basal area with the minimum measured stand density index (SDI) of 175 , mean SDI of 691 and maximum measured SDI of 1118 (metric units)

tree $\mathrm{BA}$ also predicted belowground biomass well $\left(\mathrm{R}_{\text {adj. }}^{2}=\right.$ 0.95), but the p-value for SDI was 0.14. The difference in $\mathrm{AIC}_{\mathrm{c}}$ between this model and the best model was 2.58 (Table 2), indicating that its level of empirical support was substantially less than the best model. Competing models without SDI also had high $\mathrm{R}^{2}$ values but much larger $\mathrm{AIC}_{\mathrm{c}}$ indicating significantly less empirical support than the best model.
Because C content of each root system was calculated from belowground biomass, allometric models of belowground $\mathrm{C}$ closely followed the trends observed in belowground biomass. The model using BA, SDI, and crown position resulted in the highest adjusted $\mathrm{R}^{2}$ value $\left(\mathrm{R}^{2}\right.$ adj. $\left.=0.96\right)$ but there was uncertainty around model coefficients for SDI $(\mathrm{p}=0.12)$ and position $(\mathrm{p}=0.14)$. Using only BA to predict belowground $\mathrm{C}$ produced the best model in terms of $\mathrm{AIC}_{\mathrm{c}}$ $\left(\mathrm{R}_{\text {adj. }}^{2}=0.95\right.$, Table 2, Fig. 3). Implementing the best model to estimate belowground $\mathrm{C}$, a tanoak with the average $\mathrm{BA}$ of $0.076 \mathrm{~m}^{2}$ was expected to hold $48 \mathrm{~kg}$ of $\mathrm{C}$ in its root system. The largest sample tree of $52.4 \mathrm{~cm}$ dbh was predicted to store $168.2 \mathrm{~kg}$ of $\mathrm{C}$ belowground (Table 1). The difference in $\mathrm{AIC}_{\mathrm{c}}$ between the model using BA and SDI and the best model was 2.63 , indicating substantially more empirical support for the simpler model of belowground C. A large difference in $\mathrm{AIC}_{\mathrm{c}}$ between the other models and the best model indicated that their estimates of belowground $\mathrm{C}$ had significantly less empirical support (Table 2).

\section{Discussion \\ Tanoak Root-to-Shoot Ratio}

Tanoak has the potential to store large amounts of $\mathrm{C}$ belowground. The tanoaks excavated at the LWSDTF had a mean $\mathrm{R}: \mathrm{S}$ ratio (0.35) above the typical range of $0.2-0.3$ for most temperate species (Cairns et al. 1997). In addition to variations among species, R:S ratios also vary widely within tree species. Our tanoak sample trees had a narrower range of root-shoot ratios (0.11-0.65) than Pinus taeda L. (0.20-0.83, Monk 1966), but a wider range than Acer saccharum Marsh. (0.18-0.47), Betula lutea Michx. (0.15-0.37), Fagus grandifolia Ehrh. (0.15- 
Table 2. Tanoak belowground biomass and carbon models - goodness of fit in terms of Akaike's Information Criterion for small samples $\left(A I C_{c}\right)$, square root of the mean squared error (RMSE), and the adjusted $R^{2}\left(R^{2}{ }_{\text {adj }}\right.$. of linear mixed models predicting belowground biomass and carbon in tanoak using blocks as the random effect. The global model included tree height (Ht), crown volume (CrownVol), basal area ( $/ n B A$ ), interaction between canopy position and basal area (Dom* InBA), stand density index (SDI), as well as dummy variables for multiple versus single stemmed tanoak (Mult) and crown position (Dom). $n=12$ trees

\begin{tabular}{|c|c|c|c|c|}
\hline Candidate models & $\mathrm{AIC}_{\mathrm{c}}$ & $\Delta \mathrm{AIC}_{\mathrm{c}}^{*}$ & RMSE & $\mathbf{R}_{\text {adj. }}^{2}$ \\
\hline \multicolumn{5}{|l|}{$\ln$ (Belowground biomass) $=$} \\
\hline \multicolumn{5}{|l|}{$3.217+0.0642(\mathbf{H t})+0.00061($ CrownVol $)-0.1882($ Mult $)+$} \\
\hline $3.075(\mathbf{D o m})+0.1223(\ln \mathbf{B A})+0.7794\left(\ln \mathbf{B} \mathbf{A}^{*} \mathbf{D o m}\right)-0.00057($ SDI $)$ & 49.41 & 33.49 & 0.2907 & 0.9548 \\
\hline $5.843+0.8247(\mathbf{D o m})+0.5916(\ln \mathbf{B A})-0.000493($ SDI $)$ & 27.62 & 11.70 & 0.2791 & 0.9610 \\
\hline $5.461+0.8225(\ln \mathbf{B A})+0.5812(\mathbf{D o m})$ & 24.58 & 8.66 & 0.3196 & 0.9482 \\
\hline $7.058+0.8257(\ln \mathbf{B A})-0.000492($ SDI $)$ & 18.50 & 2.58 & 0.3103 & 0.9524 \\
\hline $6.683+0.8149(\ln \mathbf{B A})$ & 15.92 & 0 & 0.3408 & 0.9425 \\
\hline \multicolumn{5}{|l|}{$\ln ($ Belowground carbon $)=$} \\
\hline \multicolumn{5}{|l|}{$2.494+0.6417(\mathbf{H t})+0.00057($ CrownVol $)+0.1802($ Mult $)+$} \\
\hline $3.052(\mathbf{D o m})+0.5089(\ln \mathbf{B A})-0.7714\left(\ln \mathbf{B} \mathbf{A}^{\star} \mathbf{D o m}\right)-0.00057($ SDI $)$ & 49.43 & 33.55 & 0.2915 & 0.9580 \\
\hline $5.116+0.8324(\mathbf{D o m})+0.5903(\ln \mathbf{B A})-0.000490($ SDI $)$ & 27.60 & 11.62 & 0.2789 & 0.9611 \\
\hline $4.746+0.5801(\ln \mathbf{B A})-0.8302($ Dom $)$ & 27.57 & 11.69 & 0.3188 & 0.9498 \\
\hline $6.342+0.8266(\ln \mathbf{B A})-0.000489($ SDI $)$ & 18.51 & 2.63 & 0.3109 & 0.9523 \\
\hline $5.970+0.8158(\ln \mathbf{B A})$ & 15.88 & 0 & 0.3408 & 0.9427 \\
\hline
\end{tabular}

${ }^{*} \Delta \mathrm{AIC}_{\mathrm{c}}=$ increase in $\mathrm{AIC}_{\mathrm{c}}$ from the best model in terms of $\mathrm{AIC}_{\mathrm{c}}$

0.47), Picea rubens Sarg. (0.41-0.54) (Whittaker et al. 1974), Fagus sylvatica L. (0.04-0.13), or Picea abies (L.) H. Karst. (0.15-0.30) (Bolte et al. 2004). The high variability in tanoak $\mathrm{R}: \mathrm{S}$ biomass ratio relative to many other species suggests plasticity of carbon allocation and storage, and the potential to enhance belowground $\mathrm{C}$ storage through management.

To study the effect of latitudinal, edaphic, and climate related variables, R:S ratio data can be aggregated by forest type (Cairns et al. 1997). In northeastern China, tree R:S averaged 0.27 but varied among the 12 species sampled from conifer and mixed broadleaf forests (He et al. 2018). The same or similar R:S was reported for the subalpine coniferous type (0.27) and the mesic deciduous hardwood (0.25) types in the USA, while slightly lower allocation of biomass belowground was reported for Douglas-fir in the USA (0.21) and spruce forests in Canada (0.23) (Cairns et al. 1997). Root-to-shoot ratios are often highest and most variable in the tropics (Waring and Powers 2017), but temperate forest R:S ratios have also been shown to vary as widely as 0.1 to 0.5 (Cairns et al. 1997). Although large differences in R:S ratios are not uncommon (Monk 1966), we introduced uncertainty in our results by not directly sampling aboveground biomass. Instead, we applied Snell and Little's (1983) models for tanoak in the northwestern USA. Their models use dbh to predict bole volume and crown mass with relatively high precision $\left(\mathrm{R}^{2}=0.98\right.$ bole, $\mathrm{R}^{2}=0.94$ crown, n=31; Snell and Little 1983). However, the uncertainty associated with these estimates was not explicitly accounted for within our analysis. Direct measurement of the stem and crown of trees used to develop models of belowground biomass would likely improve R:S ratio estimates in tanoak.

Allometric models of belowground biomass allocation can have limited applicability to field conditions, and generally do not account for competition among trees (Lacau 2003). Most studies of R:S ratio have focused on small saplings (Van Hees and Clerkx 2003; Devine and Harrington 2009) or containerized seedlings (Bernier et al. 1995; George et al. 1997; Sandstrom and Keane 1999), producing results with limited application to adult trees in natural ecosystems. Similarly, studies on tree roots have been conducted using pot experiments in highly controlled environments, limiting inductions about whether or how plants detect the presence of neighbors belowground because only one plant was grown in each pot (Casper et al. 1998). Our study, alternatively, explored how ecological factors such as stand density affected the R:S ratio of different sized tanoaks. Root-to-shoot ratio in tanoak was lower among larger trees, agreeing with the findings of other studies quantifying R:S ratio (Monk 1966; Whittaker et al. 1974) and is consistent with lower R:S with advancing age in Quercus forests of central China (Yang et al. 2019). The tanoaks in our study had lower R:S ratios in denser stands, consistent with findings of Newton and Cole (1991) that trees in more crowded stands allocated proportionally greater 

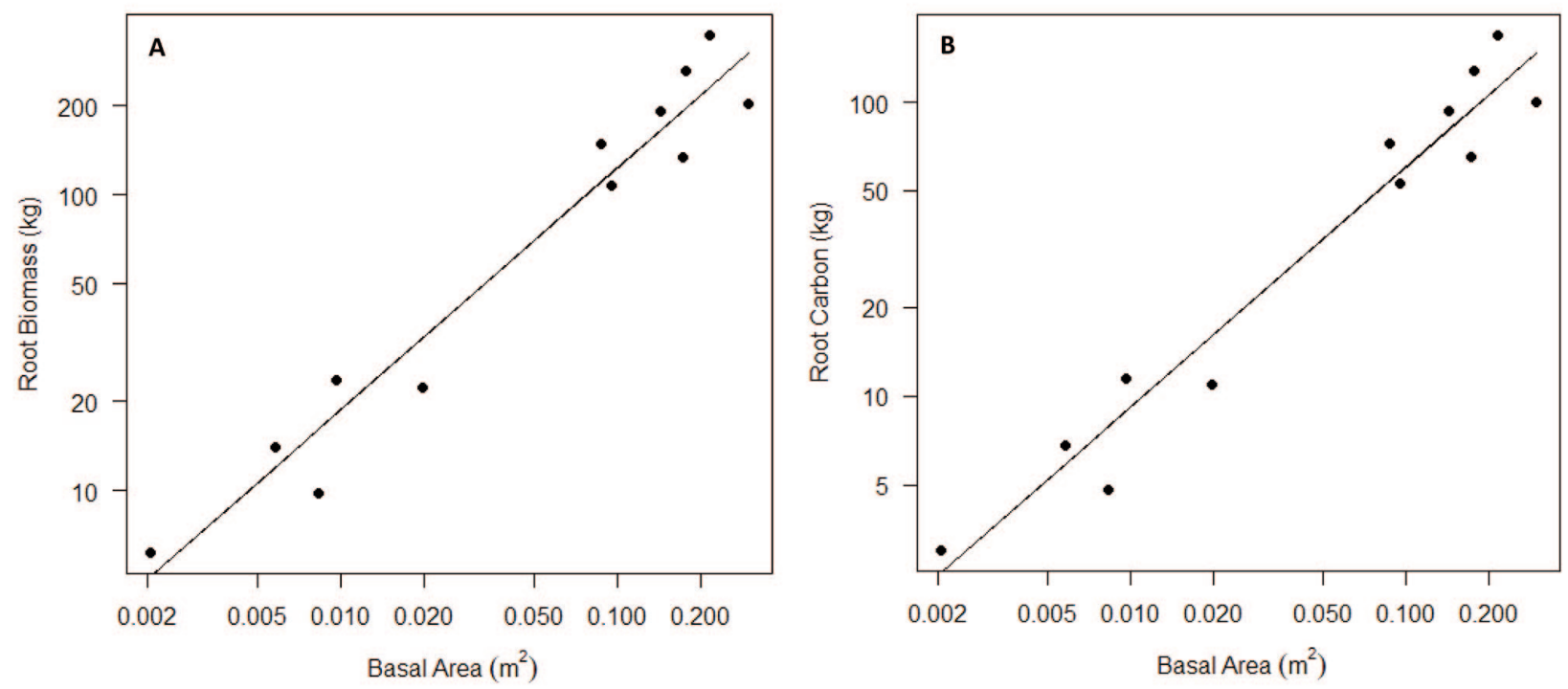

Fig. 3 Belowground biomass (a) and root carbon mass (b) regressed against tree basal area for 12 tanoaks excavated at the L.W. Schatz Demonstration Tree Farm in Humboldt County, CA. Total basal area in multiple-stemmed tanoak obtained by using the sum of each stem's basal area

biomass aboveground. Similarly, European beech (Fagus sylvatica $\mathrm{L}$.) allocated more nutrients and energy to the shoot when aboveground competition was present resulting in lower $\mathrm{R}: S$ ratios (Bolte et al. 2004). Shade has been shown to strongly affect biomass allocation to roots of Norway spruce (Picea abies [L.] Karst.) and European beech seedlings (Schall et al. 2012), but crown position (a corollary of shade) was not found to affect R:S ratios in our tanoak sample. One explanation may be tanoak's shade tolerance (Tappeiner et al. 1990). Shady conditions may have a weaker effect on biomass allocation in tanoak, a species adapted to low-light levels, compared to a shade-intolerant species, like Norway spruce, that must allocate more biomass aboveground to maintain better canopy position and access to light.

\section{Belowground biomass and $\mathrm{C}$}

We found strong correlations between belowground biomass and $C$ in tanoak and the easily measurable parameter of tree BA. We hypothesized that stem circumference at dbh would be a better predictor and a more physiologically appropriate variable due to the concentration of water and nutrient transport near the cambium (Pallardy 2008). Sapwood crosssectional area might be the ideal correlate but would be difficult to measure in tanoak. We found that stem circumference at breast height outside bark was a useful predictor of root biomass or $C\left(R^{2}=0.94\right)$, but was slightly inferior to tree $B A$ $\left(\mathrm{R}^{2}=0.95\right)$. Future research might include leaf area, or its corollary, sapwood cross-sectional area, as well as conductive tissue within the roots into allometric biomass and C models. Sampling across different sites with different soils and climate is also advisable. While Namm and Berrill (2016) observed maximum rooting in tanoaks of approximately $1-\mathrm{m}$, Tappeiner et al. (1990) reported a deep tap root in tanoak, allowing it to co-exist with shallow-rooted redwoods. These different ob- servations may be due to variation in root morphology and R:S associated with differing soil properties (Fitter et al. 1991; Fortier et al. 2015, 2017) or tree age (Kalliokoski et al. 2010; Bijak et al. 2013). Nevertheless, we expect our allometric models for tanoak to give better predictions than any single R:S ratio for the species or forest type (Hunziker et al. 2014). In our sample, tanoak tree size explained $95 \%$ of the variation in belowground $\mathrm{C}$ which is consistent with allometric model goodness-of-fit for several other tree species (e.g., Kusmana et al. 2018).

Our findings have management implications for landowners growing Douglas-fir and redwood mixed with tanoak. Trees allocate proportionally more biomass belowground after thinning (Kneeshaw et al. 2002; Nicoll et al. 2019). Therefore landowners harvesting their stands may decide to retain large widely-spaced tanoaks in managed stands to store C. However, heavy cutting in dense stands should be avoided because it will leave tanoak with low R:S vulnerable to windthrow. Another benefit of retaining tanoak trees at harvest is to cast shade and reduce moisture stress that can hinder conifer establishment on dry exposed sites such as recent clear-cuts and south-facing slopes (Minore 1986). Problems arise when tanoak dominates after stand-replacing disturbances, such as wildfires and timber harvests, and forms a dense canopy layer (Tappeiner et al. 1990). Heavy shade under tanoak canopies restricts the growth of conifers (Harrington and Tappeiner 1991; Hunter and Barbour 2001). Therefore, we advise caution when maintaining higher tanoak densities for $\mathrm{C}$ sequestration due to the impact tanoak can have on conifer regeneration and growth (Tappeiner et al. 2007; Berrill and O'Hara 2016) and the negative impact of stand density on tanoak R:S ratio. For example, a doubling of SDI (from 500 to 1000 metric units) for a tanoak of average measured $\mathrm{dbh}(31.1 \mathrm{~cm})$ resulted in $22 \%$ decrease in belowground C. 


\section{Application to inventory data}

We applied our allometric models of belowground $\mathrm{C}$ in tanoak to data collected from permanent 0.04 ha plots at the LWSDTF. Eleven plots with a low proportion of tanoak (containing only one or two tanoak per plot with tanoak representing $1 \%$ to $19 \%$ of stand BA) were predicted to hold an average of 4.7 tons of belowground tanoak $\mathrm{C} \mathrm{ha}^{-1}$. Eleven inventory plots with a greater proportion of tanoak (10 to 29 tanoak per plot representing $33 \%$ to $100 \%$ of stand $\mathrm{BA}$ ) had an average of 58.7 tons of belowground tanoak $\mathrm{C} \mathrm{ha}^{-1}$. It was not surprising that plots with a greater proportion of tanoak BA stored more $\mathrm{C}$ in tanoak root systems, but the plots dominated by tanoak had more than ten times the amount of belowground C compared to the plots sparsely composed of tanoak. This difference in tanoak's belowground $C$ is relevant because tanoak abundance and associated species composition varies according to management and by site and ecosystem (Tappeiner et al. 1990). Developing belowground $\mathrm{C}$ models for associated species and collecting data throughout tanoak's range to examine patterns of $\mathrm{C}$ allocation in relation to geographic differences, soils, and stand density will help us predict the impact of different silvicultural prescriptions or SOD induced mortality on California's C storage and sequestration.

Sudden oak death had not reached the LWSDTF where our study took place but tanoaks are very susceptible to the disease and tanoak mortality occurs quickly after inoculation (McPherson et al. 2010). Elsewhere tanoak decline is evident, especially in the redwood region of northern California (Meentemeyer et al. 2004; Maloney et al. 2005; McPherson et al. 2010; Ramage and O'Hara 2010). The estimates of belowground $\mathrm{C}$ stored in the LWSDTF plots demonstrated how much C can be stored in mixed forests within tanoak root systems, and the magnitude of possible atmospheric release of belowground $\mathrm{C}$ resulting from SOD-induced tanoak mortality and decomposition. Given the great extent of tanoak on the west coast of North America, our results highlight the importance of tanoak in regional C storage.

\section{Acknowledgements}

We are grateful for advice and assistance from Christa Dagley, Christopher Edgar, George Pease, Gordon Schatz, Steve Sillett, Morgan Varner, and root simulation modeling assistance from Jim Garner. We are indebted to volunteer field and laboratory assistants: Janina Dierks, Tyler Holquist, Jeromy Couch, Ethan Coonan, Matthew Cocking, Holly Leoparti, Chris Hightower, Chris Valness, Bobby Howe, Chris Beal, Morgan Luth, Lonnie Mauck, and Alexander Taylor. This research was funded by the Humboldt State University L.W. Schatz Demonstration Tree Farm and the McIntire-Stennis Cooperative Forestry Research Program.

\section{References}

Baker, F.S. 1949. A revised tolerance table. J. Forest. 47: 179-181.

Bernier, P.Y., M.S. Lamhamedi and D.G. Simpson. 1995. Shoot:root ratio is of limited use in evaluating the quality of container conifer stock. Planters' Notes. 46(3): 102-106.

Berrill, J-P. and K.L. O'Hara. 2014. Estimating site productivity in irregular stand structures by indexing basal area or volume increment of the dominant species. Can. J. For. Res. 44(1): 92-100. https://doi.org/10.1139/cjfr-2013-0230.
Berrill, J-P. and K.L. O’Hara. 2016. How do biophysical factors contribute to height and basal area development in a mixed multiaged coast redwood stand? Forestry. 89: 170-181. https://doi.org/ 10.1093/forestry/cpv049.

Berrill, J-P. and R.A. Howe. 2019. Multiaged redwood responds well to partial harvest and herbicide treatments. Can. J. For. Res. 49(11): 1425-1433. https://doi.org/10.1139/cjfr-2019-0142.

Berrill, J-P., K.A. Schneider, C.M. Dagley and L.A. Webb. 2018. Understory light predicts stump sprout growth in mixed multiaged stands in north coastal CA. New Forests. 49(6): 815-828. https://doi.org/10.1007/s11056-018-9636-6.

Bijak S., M. Zasada, A. Bronisz, K. Bronisz, M. Czajkowski, L. Ludwisiak, R. Tomusiak and R. Wojtan. 2013. Estimating coarse roots biomass in young silver birch stands on post-agricultural lands in central Poland. Silva Fennica. 47(2): 1-14. http://dx.doi.org/ 10.14214/sf.963.

Böhm, W. 1979. Methods of studying root systems. Springer, Berlin. http://dx.doi.org/10.1007/978-3-642-67282-8.

Bolte, A., T. Rahmann, M. Kuhr, P. Pogoda, D. Murach and K.V. Gadow. 2004. Relationships between tree dimensions and coarse root biomass in mixed stands of European beech (Fagus sylvatica L.) and Norway spruce (Picea abies [L.] Karst.). Plant Soil. 264: 1-11. http://dx.doi.org/10.1023/B:PLSO.0000047777.23344.a3.

Brassard, B.W., H.Y. Chen and Y. Bergeron. 2009. Influences of environmental variability on root dynamics in northern forests. Cr. Rev. Plant. Sci. 28: 179-197. http://dx.doi.org/10.1080/ 07352680902776572 .

Burnham, K.P. and D.R. Anderson. 2008. Model Selection and Multimodel Inference: A Practical Information-Theoretic Approach, 2nd ed. Springer-Verlag. New York, NY. http:// dx.doi.org/10.1007/b97636.

Cairns, M.A., S. Brown, E.H. Helmer and G.A. Baumgardner. 1997. Root biomass allocation in the world's upland forests. Oecologia. 111: 1-11. http://dx.doi.org/10.1007/s004420050201.

California Climate Action Registry. 2007. Forest Sector Protocols: Version 2.1 Available online at http://www.climateregistry.org/ PROTOCOLS/FP/. [Accessed March 10, 2012]. Not in the text

Casper, B.B., J.F. Cahill and L.A. Hayatt. 1998. Above-ground competition does not alter biomass allocation to roots in Abutilon theophrasi. New Phytol. 140: 231-238. http://dx.doi.org/10.1046/ j.1469-8137.1998.00271.x.

Colwell, W., J. DeLapp and E. Gladish. 1957. Soil-vegetation map for California quadrangle 26B-4, Humboldt County, CA. United States Forest Service - United States Department of Agriculture, Division of Agricultural Science - University of California, Division of Forestry - California Department of Natural Resources.

Devine, W.D. and T.B. Harrington. 2009. Belowground competition from overstory trees influences Douglas-fir sapling morphology in thinned stands. New Forest. 37: 137-153. http://dx.doi.org/ 10.1007/s11056-008-9114-7.

Drexhage, M. and F. Colin. 2001. Estimating root system biomass from breast-height diameters. Forestry 74 (5): 491-497. http://dx.doi.org/10.1093/forestry/74.5.491.

Fitter, A.H., T.R. Stickland, M.L. Harvey and GW. Wilson. 1991. Architectural analysis of plant root systems: 2 . Influence of nutrient supply on architecture in contrasting plant species. New Phytol. 118(3): 375-382. http://dx.doi.org/10.1111/j.1469-8137.1991.tb00019.x. Fortier, J., B. Truax, D. Gagnon and F. Lambert. 2015. Plastic allometry in coarse root biomass of mature hybrid poplar plantations. Bioenerg. Res. 8(4): 1691-1704. http://dx.doi.org/10.1007/ s12155-015-9621-2.

Fortier, J., B. Truax, D. Gagnon and F. Lambert. 2017. Allometric equations for estimating compartment biomass and stem volume in mature hybrid poplars: General or site-specific? Forests 8: 309. doi:10.3390/f8090309. 
George, E., B. Seith, C. Schaeffer and H. Marschner. 1997. Response of Picea, Pinus and Pseudotsuga roots to heterogeneous nutrient distribution in soil. Tree Physiol. 17: 39-45. http:// dx.doi.org/10.1093/treephys/17.1.39.

Harrington, T.B. and J.C. Tappeiner II. 1991. Competition affects shoot morphology, growth duration, and relative growth-rates of Douglas-fir saplings. Can. J. For. Res. 21: 474-481. http://dx.doi.org/ 10.1139/x91-064.

Harrington, T.B. and R.J. Pabst. 1994. Seasonal physiology of Douglas-fir saplings: Response to microclimate in stands of tanoak or Pacific madrone. For. Sci. 40(1): 59-82. https://doi.org/10.1139/ X09-004.

Harrington, T.B. and J.C. Tappeiner II. 1997. Growth responses of young Douglas-fir and tanoak 11 years after various levels of hardwood removal and understory suppression in southwestern Oregon, USA. For. Ecol. Manag. 96: 1-11. http://dx.doi.org/ 10.1016/S0378-1127(97)00049-2.

Harrington, T.B. and J.C. Tappeiner II. 2009. Long-term effects of tanoak competition on Douglas-fir stand development. Can. J. For. Res. 39: 765-776. http://dx.doi.org/10.1139/X09-004.

He, H., C. Zhang, X. Zhao, F. Fousseni, J. Wang, H. Dai, S. Yang and Q. Zuo. 2018. Allometric biomass equations for 12 tree species in coniferous and broadleaved mixed forests, Northeastern China. PLoS ONE. 13(1): e0186226. https://doi.org/ 10.1371/journal.pone.0186226.

Hunter, J.C. 1997. Fourteen years of mortality in two old-growth Pseudotsuga-Lithocarpus forests in Northern California. J. Torrey Bot. Soc. 124: 273-279.

Hunter, J.C. and M.G. Barbour. 2001. Through-growth by Pseudotsuga menziessii: A mechanism for change in forest composition without canopy gaps. J. Veg. Sci. 12: http://dx.doi.org/445-452. $10.2307 / 3236996$.

Hunziker, M., B.D. Sigurdsson, G. Halldorsson, W. Schwanghart and N. Kuhn. 2014. Biomass allometries and coarse root biomass distribution of mountain birch in southern Iceland. Icelandic Agr. Sci. 27: 11-35.

Huxley, J.S. and G. Teissier. 1936. Terminology of relative growth. Nature. 137(3471): 780. https://doi.org/10.1038/137780b0.

Kalliokoski, T., R. Sievanen and P. Nygren. 2010. Tree roots as self-similar branching structures, axis differentiation and segment tapering in coarse roots of three boreal forest tree species. TreesStruct. Func. 24: 219-236. http://dx.doi.org/10.1007/s00468-0090393-1.

Kneeshaw, D.D., H. Williams, E. Nikinmaa and C. Messier. 2002. Patterns of above- and below-ground response of understory conifer release 6 years after partial cutting. Can. J. For. Res. 32, 255265. http://dx.doi.org/10.1139/x01-190.

Kuljian, H. and J.M. Varner. 2010. The effects of Sudden Oak Death on crown fire potential in California's tanoak forests. For. Ecol. Manag. 259: 2103-2110. https://doi.org/10.1016/j.foreco. 2010.02.022.

Kusmana, C., T. Hidayat, T. Tiryana and O. Rusdiana, O. (2018). Allometric models for above-and below-ground biomass of Sonneratia spp. Glob. Ecol. Conserv. 15, e00417.

Lacau, P. 2003. Root biomass and carbon storage of ponderosa pine in northwestern Patagonia plantation. For. Ecol. Manag. 173: 353-360. https://doi.org/10.1016/S0378-1127(02)00012-9. Maloney, P.E., S.C. Lynch, S.F. Kane, C.E. Jensen and D.M. Rizzo. 2005. Establishment of an emerging generalist pathogen in redwood forest communities. J. Ecol. 93(5): 199-205. http://dx.doi.org/ 10.1111/j.1365-2745.2005.01031.x.

McDaniel, P. 2012. The twelve soil orders: Ultisol. http:// soils.cals.uidaho.edu/soilorders/ultisols.html/, [accessed May 2012]. McPherson, B.A., S.R. Mori, D.L. Wood, M. Kelly, A.J. Storer, P. Svihra and R.B. Sandiford. 2010. Responses of oaks and tanoaks to the sudden oak death pathogen after $8 \mathrm{y}$ of monitoring in two coastal California forests. For. Ecol. Manag. 259: 2248-2255. http://dx.doi.org/10.1016/j.foreco.2010.02.020.

Meentemeyer, R., D. Rizzo, W. Mark and E. Lotz. 2004. Mapping the risk of establishment and spread of sudden oak death in California. For. Ecol. Manag. 200: 195-214. http://dx.doi.org/10.1016/ j.foreco.2004.06.021.

Metz, M.R., K.M. Frangioso, R.K. Meentemeyer and D.M. Rizzo. 2011. Interacting disturbances: Wildfire severity affected by stage of forest disease invasion. Ecol. Appl. 21(2): 313-320. http:// dx.doi.org/10.1890/10-0419.1

Minore, D. 1986. Effects of madrone, chinquapin, and tanoak sprouts on light intensity, soil moisture, and soil temperature. Can. J. For. Res. 16: 654-658. https://doi.org/10.1139/x86-113.

Monk, C.D. 1966. Root-shoot dry weights in Loblolly Pine. Bot. Gaz. 127(4): 246-248.

Namm, B.H. and J-P. Berrill. 2012. Accounting for variation in root wood density and percent carbon in belowground carbon estimates. In: Standiford, R.B., Weller, T.J., Piirto, D.D., Stuart, J.D. (Tech. Coords.). Proceedings of the coast redwood forests in a changing California: A symposium for scientists and managers. pp. 283-292. United States Department of Agriculture Forest Service, Pacific Southwest Research Station (PSW-GTR-238), Albany, CA. Namm, B.H. and J-P. Berrill. 2016. Tanoak (Notholithocarpus densiflorus) coarse root morphology: Prediction models of volume and biomass of individual roots. Open J. For. 6: 1-13. https://doi.org/ 10.4236/ojf.2016.61001.

Newton, M. and E.C. Cole. 1991. Root development in planted Douglas-fir under varying competitive stresses. Can J. For. Res. 21: 25-31. https://doi.org/10.1139/x91-004.

Nicoll, B.C., T. Connolly and B.A. Gardiner. 2019. Changes in spruce growth and biomass allocation following thinning and guying treatments. Forests 10, 253. https://doi.org/10.3390/f10030253. Niklas, K.J. 2004. Plant allometry: Is there a grand unifying theory? Biol. Rev. 79: 871-899. http://dx.doi.org/10.1017/S1464793 104006499.

Pallardy, S.G. 2008. Physiology of Woody Plants, $3^{\text {rd }}$ ed. Academic Press. Burlington, Ma.

Prism Climate Group. 2019.30 Year Normals [online]. Available from http://www.prism.oregonstate.edu [accessed 28 September 2019].

R Development Core Team. 2017. R: A Language and Environment for Statistical Computing. R Foundation for Statistical Computing, Vienna, Austria. https://www.R-project.org/.

Ramage, B.S. and K.L. O'Hara. 2010. Sudden oak death in redwood forests: Vegetation dynamics in the wake of tanoak decline. In: Frankel, S.J., Kliejunas, J.T., Palmieri, K.M. (Tech. Coords.). Proceedings of the Sudden Oak Death Fourth Science Symposium. pp. 213-216. United States Department of Agriculture Forest Service, Pacific Southwest Research Station (PSW-GTR-229), Albany, CA. Ramage, B.S., K.L. O'Hara and A.B. Forrestel. 2011. Forest transformation resulting from an exotic pathogen: Regeneration and tanoak mortality in coast redwood stands affected by sudden oak death. Can. J. For. Res. 41: 763-772. http://dx.doi.org/10.1139/x11-020. Rizzo, D.M., M. Garbelotto and E.M. Hanson. 2005. Phytophthora ramorum: Integrative research and management of an emerging pathogen in California and Oregon forests. Annu. Rev. Phytopathol. 43: 309-335. http://dx.doi.org/10.1146/annurev.phyto.42.040803. 140418.

Rizzo, D.M., M. Garbelotto, J.M. Davidson, G.W. Slaughter and S.T. Koike. 2002. Phytophthora ramorum as the cause of extensive mortality of Quercus spp. and Lithocarpus densiflorus in California. Plant Dis. 86(3): 205-214. http://dx.doi.org/10.1094/PDIS.2002. 86.3.205. 
Sandstrom, E. and Keane, M. 1999. Root architecture, early development and basal sweep in containerized and bare-rooted Douglasfir (Pseudotsuga menziesii). Plant Soil. 217: 65-87. http://dx.doi.org/ 10.1007/978-94-017-3469-1_8.

SAS Institute Inc. 2011. SAS/STAT 9.3 User's Guide. Cary, NC: SAS Institute Inc. 376 p.

Schall, P., C. Lödoge, M. Beck and C. Ammer. 2012. Biomass allocation to roots and shoots is more sensitive to shade and drought in European beech than in Norway spruce seedlings. For. Ecol. Manag. 266: 246-253. http://dx.doi.org/10.1016/j.foreco.2011.11.017.

Snell, J.A.K. and S.N. Little. 1983. Predicting crown weight and bole volume of five western hardwoods. United States Department of Agriculture Forest Service, Pacific Northwest Forest and Range Experimental Station (PNW - 151), Portland, OR.

Tappeiner, J.C. II., P.M. McDonald and D.F. Roy. 1990. Lithocarpus densiflorus (Hook. and Arn.) Rehd, In: Burns, Russell, M., Honkala, Barbara, H. (Tech. Coords.), Silvics of North America: Volume 2 - Hardwoods. pp. 827-842. United States Department of Agricultural Handbook 654, Washington, D.C.

Tappeiner, J.C. II., D.A. Maguire and T.B. Harrington. 2007. Silviculture and ecology of western US forests. Oregon State University Press.
Van Hees, A.F.M. and A.P.P.M. Clerkx. 2003. Shading and rootshoot relations in saplings of silver birch, pedunculate oak, Devine and Harrington, and beech. For. Ecol. Manag. 176: 439-448.

Waring, B.G., and J.S. Powers. 2017. Overlooking what is underground: Root:shoot ratios and coarse root allometric equations for tropical forests. For Ecol. Manag. 385: 10-15.

West, C. 2007. A comparison of high spatial resolution images for fine scale vegetation mapping. Master thesis, Humboldt State University, Arcata, CA.

Whittaker, R.H., F.H. Bormann, G.E. Likens and T.G. Siccama. 1974. The Hubbard Brook Ecosystem Study: forest biomass and production. Ecol. Monogr. 44: 233-252. http://dx.doi.org/10.2307/ 1942313.

Williamson, G.B. and M.C. Wiemann. 2010. Measuring wood specific gravity correctly. J. Bot. 97: 519-524. http://dx.doi.org/ 10.3732/ajb.0900243. Not in the text

Yang, B., W. Xue, S. Yu, J. Zhou and W. Zhang. 2019. Effects of stand age on biomass allocation and allometry of Quercus acutissima in the central loess plateau of China. Forests. 10: 41. http://dx.doi.org/10.3390/f10010041. 